\title{
Dış Kaynak Kullanımının İşletme Finansal Performansına Etkisi: Düzce İli İmalat Sanayisinde KOBİ Yöneticileri Üzerinde Bir Araştırma
}

\author{
Kahraman ÇATI* \\ *Düzce Üniversitesi İsletme Fakültesi, Düzce \\ ** Düzce Üniversitesi Sosyal Bilimler Enstitüsü, Düzce \\ Emre ZENGIN**
}

\begin{abstract}
Özet
Bu çalışmada, KOBİ'lerin dış kaynak kullanım alanlarııın işletme finansal performansı üzerine etkisi incelenmiştir. Bunun yanında, KOBİ yöneticilerinin dıș kaynak kullanımına bakıș açıları, yöneticilerin eğitim durumlarına ve yöneticilik tecrübesine bağlı olarak incelenmiștir. Araștırma evrenini Düzce ili imalat sanayisinde faaliyet gösteren, 50 ve üzeri iş̧̧i çalıştıran KOBİ'ler oluşturmaktadır. Veri toplama yöntemi olarak anket tekniği kullanılmıştır. Araştırma sonucunda yöneticilerin dış kaynak kullanımına bakış açılarının eğitim durumuna bağlı olarak farklılık göstermediği belirlenmiştir. Yöneticilik tecrübesine bağlı olarak ise yöneticilerin dış kaynak kullanımına bakış açılarının, maliyet ve hizmet kalitesi faktörlerinde farklı olduğu saptanmıştır. Dış kaynak kullanım alanlarından ulaştırma-taşımacılık ve lojistik alanının işletmenin finansal performansına ilişkin ifadelerden pazar payı büyüklüğüne etkisinin olduğu belirlenmiștir. Yararlanılan diğer dış kaynak kullanım alanların ise ișletme finansal performansı üzerine herhangi bir etkisi olmadığı saptanmıștır. Yöneticilerin dış kaynak kullanımına bakış açılarının işletme finansal performansı ifadeleri üzerinde rekabet avantajı faktörü ile hizmet kalitesi faktörlerinde anlamlı farklılık tespit edilmiştir.
\end{abstract}

Anahtar Kelimeler: Dış kaynak kullanımı, KOBİ'ler, İşletme Performansı

\section{Impact of Outsourcing on Firm Financial Performance: A Research on SME Managers in Manufacture Industry of Düzce City}

\begin{abstract}
In this study, impact of outsourcing areas of SME on financial performance of the enterprise is inspected. In addition, perspectives of SME managers on outsourcing are inspected depending on educational status of managers and experience on management. Research environment includes SMEs operating in production industry in Duzce city which are employing 50 or more workers. Questionnaire technique is used as data gathering method. It is determined that perspectives of managers on outsourcing are not varying according to their educational status. However perspectives of managers on outsourcing are determined to vary on cost and service quality depending on their management experience. It is identified from the statements on financial performance of enterprise that transportation and logistics fields among outsourcing areas have impacts on market share ratios. It is determined that other utilized outsourcing areas have no impact on financial performance of enterprises. Meaningful variations are identified on competition advantage factor and service quality factor on financial performance of enterprise statements on perspectives of managers on outsourcing.
\end{abstract}

Key Words: Outsourcing, SMEs, Enterprise Performance.

\section{Giriş}

20. Yüzyılın son çeyreğinde başlayıp günümüze uzanan süreçte, küreselleşme ile birlikte çevre koşulları da değişmiştir. Bunun yanında hızla artan teknolojik gelişmeler, işletmeler arasındaki rekabeti artırmakta ve zorlaştırmaktadır. İşletmeler, bu zorlu rekabet şartlarında ayakta kalabilmek ve değişen şartlara hızlı uyum sağlayabilmek için, güçlü ve zayıf yönlerini değerlendirerek, çevrelerindeki firsat ve tehditlere göre, kendilerini rekabet yarışında öne geçirecek temel yeteneklerine odaklanmaktadirlar.

İşletmelerin temel yeteneklerine odaklanmasıyla, temel yetenekleri dışında kalan faaliyetlerini diğer işletmelerle işbirliği halinde temin etmesi dış kaynak kullanımı kavramını ortaya çıkarmıştır. İlk olarak 1980'li yıllardan itibaren kullanılmaya başlanan dış kaynak kullanımı (outsourcing) kavramı, bir yönetim stratejisi ve iş modeli olarak 1990’1 yıllardan itibaren yaygınlaşmaya başlamıştır ve 1981 yılında
Business Week'te çıkan bir makalede ilk kez "outsourcing" ifadesiyle literatürde kullanılmıştır (Sanal 1).

Dış kaynak kullanan işletmeler, faaliyet gösterdikleri dış çevreyi şekillendiren faktörleri tam ve kesin olarak bilmelidir. Dış çevreyle uyum içerisinde olmalı ve örgüt kültürlerini bu çerçevede sağlam bir zemine oturtmalıdırlar (Y1lmaz ve Karahan, 2010: 276). Bunu başarabilen işletmeler rekabet yarışında bir adım öne geçebilse de ilerleyen süreçte gösterecekleri performansları hayatta kalma mücadelesinde önem kazanacaktır. İşletme performansı, işletme yapısı, finansal yapı ve sermaye yapısıyla ilgili geniş bir boyut içindeki sorulara yanıt veren analiz, ölçüm değerlendirme ve yorumlarla amacına ulaşan nitel ve nicel bir çalışmadır (Kabakçı, 2008: 168). Bir değer ölçülmeden yönetilemez görüşü performans ölçümünün önemini vurgulamaktadır. Performans ölçümü finansal ve finansal olmayan konularda olabilir. Bir işletmenin performansını 
K. Çatı, I. Çömlekçi, E. Zengin / KMÜ Sosyal ve Ekonomik Araştırmalar Dergisi 17 (28): $56-672015$

ölçmek için kullanılan geleneksel ölçüler genellikle finansal konulardır ve daha çok kârlılık, maliyet ve verimlilik üzerine odaklanmıştır. Finansal olmayan performans ölçümlerinde kullanılan birçok gösterge de finansal performans ölçülerinden türetilmiştir (Kalkan, 2005: 59).

KOBİ'lerin günümüzde ekonomilerin temel yapı taşı durumunda olduğu düşünüldüğünde, bulundukları ekonomide gösterecekleri performansları, ekonominin seyrini etkileyebilmektedir. $\mathrm{Bu}$ açıdan bakıldığında KOBİ'lerin küçük işletmeler olmasına karşılık etkilerinin ne derece büyük olduğu görülebilmektedir. Küçük ve orta ölçekli işletmelerin, tanımı, nitelikleri ve sınıflandırılması hakkındaki yönetmelikte KOBİ'ler, "250 kişiden az yıllık çalışan istihdam eden ve yıllık net satış hasılatı veya mali bilançosundan herhangi biri 40 milyon Türk Lirasını aşmayan ekonomik birimler veya girişimlerdir" şeklinde tanımlanmıştır (Resmi Gazete, 2012). Türkiye'de de sanayinin temelini şüphesiz ki küçük ve orta ölçekli işletmeler oluşturmaktadır. $\mathrm{Bu}$ yüzden KOBI'ler, üzerinde titizlikle çalışılması gereken konulardandır. KOBİ'ler genelde aile işletmeleridir. $\mathrm{Bu}$ da içe kapanık bir yapı algısı oluşturmaktadır. Küreselleşmenin etkisi ve rekabet koşullarındaki sert çekişmeler KOBİ'leri; kendilerini yenileme, geliştirme ve değiştirme yoluna itmektedir. Bu bağlamda, öncelikle yönetim stratejilerinde yapacakları profesyonel bakış açılı değişim, öncelikleri olmalıdır. Yönetim stratejilerinden biri olan dış kaynak kullanımı da bu noktada işletmeleri rekabet yarışında öne geçirebilecek bir strateji olarak önemlidir.

Dış kaynak kullanımı ile ilgili hâkim görüşe göre; bir işletmenin dış kaynak kullanma isteğinin en önemli nedeni maliyetleri düşürmektir. Ancak bu genel görüşün aksine sadece maliyet unsuru dış kaynak kullanımının tek ve en önemli nedeni değildir. Maliyetleri düşürmenin yanında işletmenin temel yeteneklerini geliştirme, riski azaltma ve yayma, kaynakların yeniden dağıtımını sağlama, teknolojiyi takip edebilme, kaliteyi artırma gibi unsurlar da dış kaynak kullanımının diğer nedenleri olarak ifade edilebilir (Karahan, 2009: 186).

İşletmeler, diş kaynak kullanımı yoluyla temel yeteneklerine odaklanıp geliştirebilecek, temel yetenekleri dışında kalan faaliyetleri ise dış kaynak yoluyla sağlayarak, zaman kaybetmeyecek ve de rekabet yarışında avantaj sağlayabileceklerdir. $\mathrm{Bu}$ araştırmada, Düzce ilinde imalat sanayisinde faaliyet gösteren KOBİ'lerde dış kaynak kullanım alanlarının işletme finansal performansına etkisi incelenmiştir. Bunun yanında, KOBİ yöneticilerinin eğitim durumu ve yöneticilik tecrübesine bağlı olarak dış kaynak kullanımına ilişkin görüşlerindeki farklılıklar incelenmiştir.

\section{Literatür Calıșması}

İngilizce literatürde "outsourcing” kavramı "outside resource using" kelimelerinin kısaltması olarak kullanılmaktadır. Bu kavramın Türkçe literatürde "dış kaynak kullanımı" veya "dış kaynaklardan yararlanma" şeklinde çevirisi yapılmaktadır (Turgut, 2012: 2). Dış kaynak kullanımı, işletmelerin esas itibariyle planlama, koordinasyon ve kontrol fonksiyonlarını yerine getirerek, diğer işletmecilik faaliyetlerinde başka işletmelerin uzmanlığına başvurması, diğer bir ifadeyle dışarıya iş vermesi olarak tanımlanmaktadır (Oktay, 2006: 83). Bir başka tanıma göre, bir örgütün dâhili olarak gerçekleştirdiği bir iş, fonksiyon veya süreci dış tedarikçilere devretmesidir (Genç, 2004).

Dış kaynak kullanımı ile ilgili yapılan çok sayıdaki tanımın ortak özelliği, işletmelerin operasyonel faaliyetleri arasında yer alan, diğer bir ifadeyle temel yetenekleri arasında yer almayan işleri dışarıdaki işletmelere devretmeleri ve sahip oldukları temel yeteneğe daha fazla yoğunlaşmalarının gerektiğidir (Karacaoğlu, 2001: 4). D1ş kaynak kullanımı anlayışının temelinde "İyi yaptığın isleri bünyende tut, geri kalan faaliyetleri tedarik et" felsefesi yatmaktadır (Şahin, 2005: 14).

Temel yetenek ve diş kaynaklardan yararlanma kavramları birbirinden ayrı düşünülemeyecek kavramlardır. Temel yetenek bir işletmeye rekabet avantajı sağlayan ve müşteriye özel değer olarak yansıyan beceriler bütünü olarak tanımlanabilir. Temel yetenek kavramında çeşitli becerilerin birleşimi söz konusudur ve bunların birleşimi ile rakiplerin kolayca taklit edemeyeceği rekabet avantajı ortaya çıkmaktadır (Mucuk, 2000: 198). Coca Cola'nın marka yönetme yeteneği bu duruma örnek olarak gösterilebilir (Büber, 1999: 50).

İşletme tarafindan belirlenecek temel yeteneklerin bazı özellikleri taşıması gerekmektedir. Temel yetenekler, işletmenin kısa ve uzun dönemli yaşamı için temel sayılmalı, rakipler tarafindan kolayca görülmemeli, rakipler tarafindan taklit edilmesi güç olmalıdır. İşletmelerin vizyon ve stratejik hedeflerini gerçekleştirmesinde vazgeçilmez nitelikte olmalı, belirli bilgiler, kaynaklar ve süreden oluşan bir karışımı temsil etmeli ve sonunda temel ürün niteliği taşıacak nihai ürünlerin üretiminde kullanılabilmelidir (Erkaragülle, 2007: $5)$.

Literatüre bakıldığında, teknolojik alanda yaşanan gelişmeler, küreselleşme hareketlerinin yoğunlaşması ve dış kaynaklardan yararlanma konusunda başvurulabilecek tedarikçilerin sayısının artarak bu eğilimin kuruluşlar açısından giderek daha fazla kabul görmesi, dış kaynaklardan yararlanmanın en temel nedenleri arasında sayılmaktadır (Ataman, 2001). İşletmeleri dış kaynak kullanımına yönelten diğer nedenler, sermaye yetersizliği, bilgi eksikliği, esneklik, talebe hızlı cevap verebilme, pazar kolaylıkları ve varlıkları daha etkin kullanabilme şeklinde sıralanabilir (Heikkila and Cordon, 2002: 185).

Dış kaynak kullanımının avantaj ve dezavantajları da literatürde yapılan çalışmalarla ortaya konulmuştur. Avantajları (Jennigs, 1997; Ordoobadi, 2005; Şahin, 2005; Oktay, 2006; Özdoğan, 2006; Sanal 2; Sanal 3);

- Dış kaynak kullanımı, işletmenin katma değeri yüksek kendi temel iş süreçlerini ve yeteneklerini güçlendirmek için daha çok zaman sağlamaktadır.

- Dış kaynak kullanımı yoluyla işleme hız kazanmakta ve tedarikçilerin uzmanlıklarından faydalanabilmektedir.

- Dış kaynak kullanımı yoluyla işletme tedarikçileri ile risk paylaşımı yaparak riskini azaltmakta ve avantaj elde etmektedir.

- Dış kaynak kullanımı, sermaye gereksinimi ve iş gücü ihtiyacının azalmasını sağlamaktadır.

- Diş kaynak kullanımı yolu ile özel beceri gerektirmeden müşterilere özel hizmetler sunulabilmektedir.

- Dış kaynak kullanımı yeni sektörlerin oluşmasını ve gelişmesini sağlayarak ülke ekonomisine katkı sağlamaktadır.

- Değişik teknolojilere, kapasitelere, tecrübelere ve bilgiye erişme imkanı tanımaktadır ve değişik müşteri tabanına, sektörlere ve coğrafi konumlara erişme imkanı tanımaktadır.

Dezavantajları ve riskleri (Ordoobadi, 2005; Oktay, 2006; Özdoğan, 2006; Sanal 2; Sanal 3); 
- Tedarikçi üzerinde kontrol kaybı oluşabilmektedir. Bunun sonucunda hizmet alımı ve kalite konusunda aksaklıklar yaşanabilmektedir.

- Kritik temel beceriler kaybedilebilmekte veya yanlış temel yetenekler geliştirilebilmektedir.

- Çalışanların üzerinde olumsuz etki oluşması, moral ve motivasyonlarının düşmesine neden olarak işletmenin verimliliğini etkilemektedir.

- $\quad$ İşletmelerin gizli bilgilerinin ortaya çıkmasına neden olabilmektedir.

- Dış kaynak kullanımı maliyet avantajı sağlamasına rağmen, gizli maliyetler ortaya çıkması durumunda bu avantaj, dezavantaja dönüşebilmektedir.
Tedarikçi birden fazla işletmeye hizmet sağlayabilir. Bu durumda işletmeye karşı odak eksikliği yaşanabilir.

- $\quad$ Sektöre giriş maliyetlerinin düşmesine neden olarak hem rakip sayısının çoğalmasına, hem de kar paylarının azalmasina neden olabilmektedir.

Dış kaynak kullanımı, çeşitli avantajlar sağladığı gibi beraberinde dezavantajları ve riskleri de getirmektedir. Bu bağlamda, dış kaynak kullanımı kararı alırken karar süreci stratejik olarak değerlendirilmelidir. İşletmeyi etkileyebilecek tüm faktörler titizlikle incelenmeli ve analiz edilmelidir. Jennings (1997), dış kaynak kullanım sürecini stratejik olarak ele almış ve Şekil 1.'de görüldüğü gibi; işletmenin çevresi, maliyet unsurları, işletmenin yetenekleri, teknoloji ve tedarikçi ilişkileri şeklinde 5 temelde değerlendirmiştir.

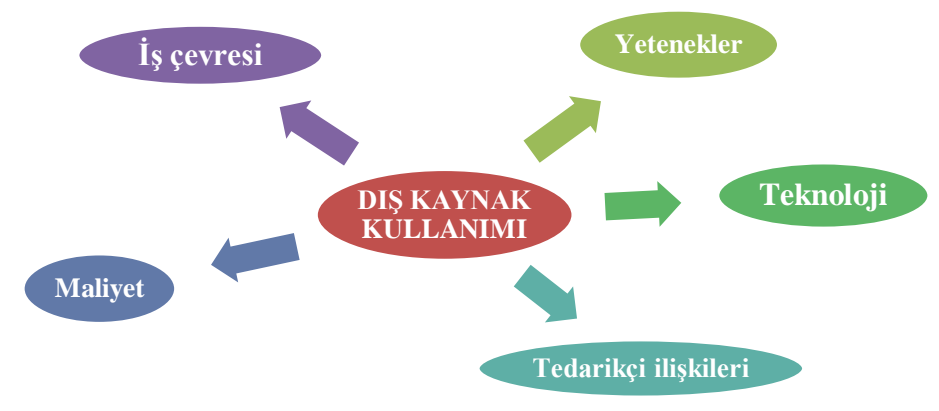

Kaynak: David Jennings, 1997: 87

Şekil 1. Dış kaynak kullanımı karar süreci kriterleri.

Dış kaynak kullanımının stratejik bir süreç olarak değerlendirilmesi, işletmenin zorlu rekabet şartlarında ayakta kalabilmesi ve kendini geliştirebilmesi açısından önemlidir. Bu bakımdan, dış kaynak kullanımı işletmenin performansını etkileyebilmektedir. Bu bağlamda literatür incelendiğinde, Görzig ve Stephan (2002), 1992- 2000 yılları arasında Alman maliyet yapısı araştırmasından alınan firma düzeyindeki panel verilerden yararlanarak deneysel analiz yapmışlardır. Sonucunda, kurum içi işgücü maliyetlerine nazaran diş hizmetlerini artıran, dolayısıyla daha önce firma bünyesinde sağlanan hizmet işlevleri için dış kaynak kullanan firmalar daha kötü performans göstermiştir. Calabrese ve Erbetta (2004), İtalya'da otomotiv sektöründe faaliyet gösteren firmaların son on yıllık mali tablolarını farklı bakış açılarıyla incelemişler ve sonucunda stratejik karlılık ve borç oranı bakımında daha iyi performans gösterdiklerini tespit etmişlerdir. Arvanitis ve Loukis (2011), ise Yunan ve İsviçre firmalarını karşılaştırmışlar. Bu çalışmada yazarlar inovasyon performansı ve bunun yanında işgücü verimliliğinin dış kaynak kullanımıyla firmalar üzerindeki etkilerini karşılaştırmalı olarak incelemişlerdir.

Türkiye'de yapılan çalışmalar ise daha çok dış kaynak kullanım alanlarının belirlenmesi üzerine yapılmıştır. Dış kaynak kullanımının işletme performansı üzerine etkisini araştıran az sayıda çalışma vardır ve bu çalışmalar daha çok hizmet sektöründe faaliyet gösteren firmalar ve kurumlar üzerinde yapılmıştır (Özdoğan, 2006; Karahan, 2009; Şağban, 2011; Karakaş, 2012; Turgut, 2012). Literatürde imalat sanayisinde dış kaynak kullanımı üzerine yapılmış çalışmalar bulunmakla beraber diş kaynak kullanımının işletme performansına etkisine ilişkin bir çalışmaya ulaşılamamıştır.
Bu bağlamda, KOBİ'lerin ülke ekonomisindeki yeri dikkate alınarak, KOBİ'lerin güçlenmesinin ve performanslarının artması ekonomiye sağlayacağı katkılarda düşünüldüğünde, bu çalışma, literatürdeki bu boşluğu doldurmak adına önem taşımaktadır.

\section{Araştırma Modeli}

$\mathrm{Bu}$ araştırmanın temel amacı; Düzce ilinde imalat sanayisinde faaliyet gösteren KOBİ'lerde dış kaynak kullanım alanlarının işletme finansal performansına etkisinin olup olmadığını ve eğer etkili ise bu etkinin ne düzeyde olduğunu ortaya koymaktır. Bu amaçla, dış kaynaklardan yararlanılan alanlar ile işletme finansal performansı arasındaki ilişkiler incelenmiş ve işletme finansal performansı üzerindeki etkilerine bakılmıştır. Bunun yanında, KOBİ yöneticilerinin eğitim durumu ve yöneticilik tecrübesine bağlı olarak dış kaynak kullanımına ilişkin görüşlerindeki farklılıklar incelenmiştir. Türkiye ekonomisi açısından KOBİ'lerin öneminden dolayı Düzce ilinde faaliyette bulunan imalat sektöründeki KOBI'ler araştırma konusu olarak belirlenmiştir. Düzce'nin teşvik bölgesinde olması ve birçok işletmenin de Düzce'yi tercih etmesi, Düzce ilinin tercih edilmesinde etkili olmuştur. İş gücünün dış kaynak yoluyla sağlanılabilme ihtimali düşünülerek 50 ve üzeri işçi çalıştıran KOBİ'ler araştırma kapsamına alınmıştır.

Araştırmanın yukarıda ki amaçları çerçevesinde oluşturulan simgesel modeli Şekil 2'deki gibidir. 


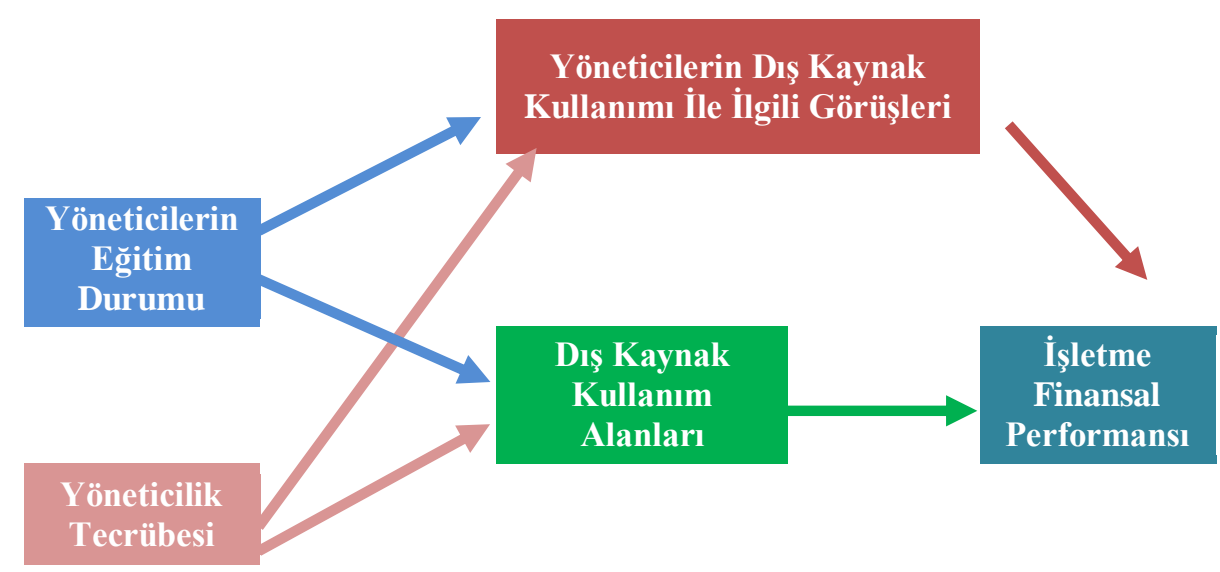

Şekil 2. Araştırma Modeli

Araştırmamıza ilişkin hipotezler ise aşağıdaki gibidir;

$\mathbf{H}_{1}$ : Yöneticilerin eğitim durumuna bağlı olarak yöneticilerin DKK kullanımı ile ilgili görüşleri arasından farklılık vardır.

$\mathbf{H}_{2}$ : Yöneticilerin yöneticilik tecrübesine bağlı olarak yöneticilerin DKK kullanımı ile ilgili görüşleri arasından farklılık vardır.

$\mathbf{H}_{3}$ : Yöneticilerin eğitim durumuna bağlı olarak DKK kullanım alanlarında farklılık vardır.

$\mathbf{H}_{4}$ : Yöneticilerin yöneticilik tecrübesine bağlı olarak DKK kullanım alanlarında farklılık vardır.

$\mathbf{H}_{5 \mathbf{a}}$ : Bilgi-işlem teknolojilerine bağlı olarak işletme finansal performansında farklılık vardır.

$\mathbf{H}_{5 \mathbf{b}}$ : Güvenlik hizmetlerine bağlı olarak işletme finansal performansında farklılık vardır.

$\mathbf{H}_{\mathbf{5}}$ : Eğitim faaliyetlerine bağlı olarak işletme finansal performansinda farklılık vardır.

$\mathbf{H}_{\mathbf{5 d}}$ : Tanıtım ve reklam alanlarına bağlı olarak işletme finansal performansinda farklılik vardır.

$\mathbf{H}_{5 \mathrm{e}}$ : Muhasebe ve finans alanına bağlı olarak işletme finansal performansında farklılık vardır.

$\mathbf{H}_{\mathbf{5 f}}$ : Ulaştırma - taşımacılık - lojistik alanına bağlı olarak işletme finansal performansında farklılık vardır.

$\mathbf{H}_{\mathbf{5 g}}$ : Temizlik Hizmetlerine bağlı olarak işletme finansal performansında farklılık vardır.

$\mathbf{H}_{5 \mathbf{h}}$ : Teknik bakım hizmetine bağlı olarak işletme finansal performansinda farklılık vardır.

$\mathbf{H}_{5 \mathrm{i}}$ : Yemek hizmetlerine bağlı olarak ișletme finansal performansinda farklılık vardır.

$\mathbf{H}_{6}$ : Yöneticilerin DKK' na ilişkin görüşlerine bağlı olarak finansal performansinda farklılık vardır.

\section{Araştırmanın Yöntemi}

Araştırma verilerinin elde edilme aracı olarak anket kullanılmıştır. Anket, Şahin (2005), Özdoğan (2006) ve
Karakaş'ın (2012) çalışmalarından uyarlanarak oluşturulmuştur.

$\mathrm{Bu}$ çalışma için hazırlanan anket, ana hatlarıyla dört bölümden oluşmaktadır. Birinci bölüm dış kaynak kullanım alanları, dış kaynak kullanım amaçları ve tedarikçi seçiminde dikkat edilen kriterleri kapsamaktadır. İkinci bölümde dış kaynak kullanımı etkileyen ifadelere katılım düzeyleri sorulmuştur ve 5'li Likert tipi ölçek kullanılmıştır. Üçüncü bölümde, araştırma kapsamındaki yöneticilerin finansal göstergeler ilişkin sektör ortalamalarını bildiği varsayımı altında işletmelerin finansal performansını ölçmeye yönelik maddelere yer verilmiştir. Ankete katılanlardan sektör ortalamasına göre cevaplanması istenmiştir ve 5'li Likert tipi ölçek kullanılmıştır. Dördüncü bölümde ise kuruma ve ankete katılan kurum yöneticisine ait sosyo-demografik özelliklere ilişkin değişkenler yer almaktadır. Araştırma sürecinde toplanan veriler SPSS 20.0 paket programı ile analiz edilmiştir.

$\mathrm{Bu}$ araştırma evrenini Düzce imalat sanayisinde faaliyet gösteren sanayi ve ticaret siciline kayıtlı 50 ve üzeri işçi çalıştıran KOBİ statüsündeki metal, gıda, orman, kauçukplastik, maden, mobilya ve tekstil sektöründe ki 87 firma oluşturmaktadır. Çalışmada tam sayım yöntemi kullanılmış ve ilgili firmaların tamamına ulaşılmış fakat 72'sinden veri alınabilmiştir. Veriler bizzat firma sahipleri, üst düzey yöneticileri, bölüm müdürleri veya yardımcılarıyla görüşülerek toplanmıştır.

\section{Bulgular ve Yorum}

Veri toplamak amaciyla oluşturulan anket ifadelerinin güvenirliliğini ölçmek amacıyla yapılan analiz sonucunda Cronbach Alfa $(0,70<\alpha<1)$ değeri 0,72 olarak belirlenmiştir. Nunnally'e göre (1994) bu değerin 0,70'in üstünde olması gerekmektedir. 
K. Çatı, I. Çömlekçi, E. Zengin / KMÜ Sosyal ve Ekonomik Araştırmalar Dergisi 17 (28): 56-67 2015

Tablo 1: Yöneticilere İlişkin Tanımlayıcı İstatistikler

\begin{tabular}{|c|c|c|c|c|c|}
\hline Değişkenler & Gruplar & f & $\%$ & $\overline{\mathrm{X}}$ & S.S \\
\hline \multirow{2}{*}{ Cinsiyet } & Kadın & 16 & 22,2 & \multirow{2}{*}{1,78} & \multirow{2}{*}{0,42} \\
\hline & Erkek & 56 & 77,8 & & \\
\hline \multirow{4}{*}{ Eğitim } & Lise & 7 & 9,7 & \multirow{4}{*}{2,71} & \multirow{4}{*}{0,72} \\
\hline & Ön Lisans & 11 & 15,3 & & \\
\hline & Lisans & 50 & 69,4 & & \\
\hline & Yüksek Lisans & 4 & 5,6 & & \\
\hline \multirow{9}{*}{$\begin{array}{l}\text { İşletmedeki } \\
\text { Pozisyon }\end{array}$} & Yönetim Kurulu Başkanı veya Sahibi & 5 & 6,9 & \multirow{9}{*}{4,75} & \multirow{9}{*}{2,06} \\
\hline & Genel Müdür & 9 & 12,5 & & \\
\hline & Genel Müdür Yardımcıs1 & 4 & 5,6 & & \\
\hline & Muhasebe ve Finans Müdürü & 16 & 22,2 & & \\
\hline & Üretim Müdürü & 8 & 11,1 & & \\
\hline & İnsan Kaynakları ve Personel Müdürü & 12 & 16,7 & & \\
\hline & Fabrika Müdürü & 15 & 20,8 & & \\
\hline & Planlama Sorumlusu & 1 & 1,4 & & \\
\hline & İdari İşler Sorumlusu & 2 & 2,8 & & \\
\hline \multirow{6}{*}{$\begin{array}{l}\text { Yöneticilik } \\
\text { Tecrübesi }\end{array}$} & $0-1 Y_{1} 1$ & 2 & 2,8 & \multirow{6}{*}{3,54} & \multirow{6}{*}{1,43} \\
\hline & $2-4 Y_{11}$ & 14 & 19,4 & & \\
\hline & $5-7 Y_{1 l}$ & 30 & 41,7 & & \\
\hline & $8-10 Y_{11}$ & 8 & 11,1 & & \\
\hline & $11-14 Y_{11}$ & 5 & 6,9 & & \\
\hline & 15 Y1l ve Üstü & 13 & 18,1 & & \\
\hline \multirow{6}{*}{$\begin{array}{c}\text { İşletmede Çalışma } \\
\text { Y1lı }\end{array}$} & $0-1 Y_{1}$ & 1 & 1,4 & \multirow{6}{*}{3,35} & \multirow{6}{*}{1,42} \\
\hline & $2-4 Y_{11}$ & 23 & 31,9 & & \\
\hline & $5-7 Y_{11}$ & 24 & 33,3 & & \\
\hline & $8-10$ Yil & 9 & 12,5 & & \\
\hline & $11-14 Y_{11}$ & 4 & 5,9 & & \\
\hline & 15 Y1l ve Üstü & 11 & 15,3 & & \\
\hline
\end{tabular}

Tablo 1'de sunulduğu gibi, katılımcıların 16's1 kadın, 56 'sı ise erkektir ve ayrıca \% 69,4'ü lisans eğitimi almıştır. Bununla beraber, katılimciların \% 22,2'sinin muhasebe ve finans müdürü, $\%$ 20,8'inin fabrika müdürü, \% 16,7'sinin insan kay. ve personel müdürü olduğu tespit edilmiştir.
Ayrıca, katılımcıların, \% 41,7'sinin 5-7 yıllık yöneticilik tecrübesine sahip olduğu ve \% 33,3'ünün 5-7 yıldır, \% 31,9'unun ise 2-4 yıldır işletmede çalıştığı belirlenmiştir.

Tablo 2: İşletmede Çalışan Personel Sayısına İlişkin İstatistikler

\begin{tabular}{|c|c|c|c|c|c|}
\hline Değişkenler & Gruplar & f & $\%$ & $\overline{\mathrm{X}}$ & S.S \\
\hline \multirow{8}{*}{$\begin{array}{c}\text { İşletmede Çalışan } \\
\text { Personel Sayısı }\end{array}$} & $50-74$ & 13 & 18,1 & \multirow{8}{*}{3,51} & \multirow{8}{*}{2,21} \\
\hline & $75-99$ & 17 & 23,6 & & \\
\hline & $100-124$ & 14 & 19,4 & & \\
\hline & $125-149$ & 7 & 9,7 & & \\
\hline & $150-174$ & 8 & 11,1 & & \\
\hline & 175-199 & 3 & 4,2 & & \\
\hline & $200-224$ & 2 & 2,8 & & \\
\hline & $225-250$ & 8 & 11,1 & & \\
\hline
\end{tabular}

Tablo 2'de işletmede çalışan personel sayısına ilişkin frekans ve yüzde dağılımları gösterilmiştir. 
Tablo 3: Dış Kaynak Kullanım Alanlarından Yararlanma Düzeyleri

\begin{tabular}{|c|c|c|c|c|c|}
\hline Dış kaynak Kullanım Alanları & İfadeler & $\mathbf{f}$ & $\%$ & $\overline{\mathrm{X}}$ & s.s \\
\hline \multirow{2}{*}{ Bilgi-Işlem Teknolojilerinde } & Yararlaniyoruz & 7 & 9,7 & \multirow{2}{*}{1,90} & \multirow{2}{*}{0,30} \\
\hline & Yararlanmiyoruz & 65 & 90,3 & & \\
\hline \multirow{2}{*}{ Satış-Pazarlama Alanında } & Yararlantyoruz & - & - & \multirow{2}{*}{2,0} & \multirow{2}{*}{ - } \\
\hline & Yararlanmiyoruz & 72 & 100,0 & & \\
\hline \multirow{2}{*}{ Güvenlik Hizmetleri } & Yararlaniyoruz & 45 & 62,5 & \multirow{2}{*}{1,38} & \multirow{2}{*}{0,49} \\
\hline & Yararlanmiyoruz & 27 & 37,5 & & \\
\hline \multirow{2}{*}{ Satın Alma } & Yararlantyoruz & - & - & \multirow{2}{*}{2,0} & \multirow{2}{*}{-} \\
\hline & Yararlanmiyoruz & 72 & 100,0 & & \\
\hline \multirow{2}{*}{ Eğitim Faaliyetleri } & Yararlantyoruz & 1 & 1,4 & \multirow{2}{*}{1,99} & \multirow{2}{*}{0,12} \\
\hline & Yararlanmiyoruz & 71 & 98,6 & & \\
\hline \multirow{2}{*}{ Tanitım ve Reklam } & Yararlantyoruz & 18 & 25,0 & \multirow{2}{*}{1,75} & \multirow{2}{*}{0,44} \\
\hline & Yararlanmiyoruz & 54 & 75,0 & & \\
\hline \multirow{2}{*}{ Muhasebe-Finans Alanında } & Yararlantyoruz & 23 & 31,9 & \multirow{2}{*}{1,68} & \multirow{2}{*}{0,47} \\
\hline & Yararlanmiyoruz & 49 & 68,1 & & \\
\hline \multirow{2}{*}{ Ulaştırma-Taşımacılık-Lojistik } & Yararlantyoruz & 38 & 52,8 & \multirow{2}{*}{1,47} & \multirow{2}{*}{0,50} \\
\hline & Yararlanmiyoruz & 34 & 47,2 & & \\
\hline \multirow{2}{*}{ Temizlik Hizmetleri } & Yararlantyoruz & 22 & 30,6 & \multirow{2}{*}{1,69} & \multirow{2}{*}{0,46} \\
\hline & Yararlanmiyoruz & 50 & 69,4 & & \\
\hline \multirow{2}{*}{ İnsan Kaynakları-Personel Seçimi } & Yararlantyoruz & - & - & \multirow{2}{*}{2,0} & \multirow{2}{*}{ - } \\
\hline & Yararlanmiyoruz & 72 & 100,0 & & \\
\hline \multirow{2}{*}{ Çağrı Merkezi } & Yararlantyoruz & - & - & \multirow{2}{*}{2,0} & \multirow{2}{*}{-} \\
\hline & Yararlanmiyoruz & 72 & 100,0 & & \\
\hline Teknik Bakım & Yararlantyoruz & 8 & 11,1 & 189 & 0.32 \\
\hline & Yararlanmiyoruz & 64 & 88,9 & & \\
\hline Yemek Hizmeti & Yararlantyoruz & 28 & 38,9 & 161 & 0.4 \\
\hline & Yararlanmiyoruz & 44 & 61,1 & & \\
\hline
\end{tabular}

Tablo 3'e göre araştırma kapsamındaki işletmelerin \% $62,5^{\prime}$ ' güvenlik hizmetlerinde, $\% 52,8^{\prime} \mathrm{i}$ ulaștırma ve lojistikte, $\%$ 38, $9^{\prime}$ u yemek hizmetlerinde, \% 31,9'u muhasebe ve finans alanında, \% 30,6'sı temizlik hizmetlerinde, \% 25'i de tanıtım ve reklam alanında dış kaynaklardan yararlanmaktadır. Ayrıca satış-pazarlama, satın alma, insan kaynakları-personel seçimi ve çağrı merkezi hizmetlerinde dış kaynaklardan yaralamazlarken, bilgi-işlem, eğitim faaliyetleri ve teknik bakım konularında az sayıda işletme dış kaynak kullanımına gitmektedir.
Araştırmaya katılan ișletme yöneticilerinin \% 93,'i dış kaynak kullanımının stratejik bir karar oluğunu düşünmektedir. $\mathrm{Bu}$ bağlamda Tablo 4'te işletmelerin dış kaynak kullanmadaki amaçlarına yönelik ifadelere yöneticilerin katılım düzeyleri gösterilmiştir. Tablo 4'e göre, işletmemizin söz konusu faaliyetler konusunda yetersiz olması ve faaliyet esnekliği sağlama amaçlarının ön planda olduğu görülmektedir. Kaynakları verimli kullanma ve ana faaliyet konularına odaklanma işletme yöneticilerinin yoğunlaştıkları diğer amaçlar olarak görülmektedir. 
Tablo 4: Dış Kaynak Kullanım Amaçları

\begin{tabular}{|c|c|c|c|c|c|}
\hline Dış kaynak Kullanım Amacı & İfadeler & f & $\%$ & $\bar{X}$ & S.S \\
\hline \multirow{2}{*}{$\begin{array}{l}\text { İşletmemizin söz konusu faaliyetler konusunda yetersiz } \\
\text { olmas1 }\end{array}$} & Evet & 37 & 51,4 & \multirow{2}{*}{1,49} & \multirow{2}{*}{0,50} \\
\hline & Hayır & 35 & 48,6 & & \\
\hline \multirow{2}{*}{ Faaliyet esnekliği sağlama } & Evet & 34 & 47,2 & \multirow{2}{*}{1,53} & \multirow{2}{*}{0,50} \\
\hline & Hayır & 38 & 52,8 & & \\
\hline \multirow{2}{*}{ Sabit maliyetleri değişken hale getirme } & Evet & 5 & 6,9 & \multirow{2}{*}{1,93} & \multirow{2}{*}{0,26} \\
\hline & Hayır & 67 & 93,1 & & \\
\hline \multirow{2}{*}{ Kaliteyi artırma } & Evet & 4 & 5,6 & \multirow{2}{*}{1,94} & \multirow{2}{*}{0,23} \\
\hline & Hayır & 68 & 94,4 & & \\
\hline \multirow{2}{*}{ Verimliliği artırma } & Evet & 9 & 12,5 & \multirow{2}{*}{1,88} & \multirow{2}{*}{0,33} \\
\hline & Hayır & 63 & 87,5 & & \\
\hline \multirow{2}{*}{ İşletmeye değer kazandırma } & Evet & 3 & 4,2 & \multirow{2}{*}{1,96} & \multirow{2}{*}{0,20} \\
\hline & Hayır & 69 & 95,8 & & \\
\hline \multirow{2}{*}{ Rekabet gücünü geliştirme } & Evet & 1 & 1,4 & \multirow{2}{*}{1,99} & \multirow{2}{*}{0,12} \\
\hline & Hayır & 71 & 98,6 & & \\
\hline \multirow{2}{*}{ Ana faaliyet konularına odaklanma } & Evet & 17 & 23,6 & \multirow{2}{*}{1,76} & \multirow{2}{*}{0,43} \\
\hline & Hayır & 55 & 76,4 & & \\
\hline \multirow{2}{*}{ Maliyet tasarrufu sağlama } & Evet & 9 & 12,5 & \multirow{2}{*}{1,87} & \multirow{2}{*}{0,33} \\
\hline & Hayır & 63 & 87,5 & & \\
\hline \multirow{2}{*}{ Bilgi ve becerileri artırma } & Evet & 9 & 12,5 & \multirow{2}{*}{1,87} & \multirow{2}{*}{0,33} \\
\hline & Hayır & 63 & 87,5 & & \\
\hline \multirow{2}{*}{ Teknolojiyi izleme } & Evet & 7 & 9,7 & \multirow{2}{*}{1,90} & \multirow{2}{*}{0,30} \\
\hline & Hayır & 65 & 90,3 & & \\
\hline Riskleri navlasma & Evet & 4 & 5,6 & 194 & 0.23 \\
\hline Riskıer1 paylaşma & Hayır & 68 & 94,4 & & \\
\hline Kavnakları verimli kullanma & Evet & 27 & 37,5 & 1.63 & 0,49 \\
\hline & Hayır & 45 & 62,5 & 1,03 & \\
\hline
\end{tabular}

Tablo 4'e bakıldığında işletme yöneticilerinin, dış kaynak kullanım amaçları arasında ki "maliyet tasarrufu sağlama" amacının öncelikli olmadığı görülmekle beraber $(\% 12,5)$ dış kaynak kullanımının maliyetler üzerinde olumlu bir etkiye sahip olduğu görülmektedir. Tablo 5 incelendiğinde araştırmaya katılanların \% 80,6'sı, dış kaynak kullanımının maliyetleri düşürdüğü görüşünü savunmaktadır. Bununla birlikte, dış kaynak kullanımının maliyetler üzerinde etkisi olduğunu düşünen yöneticilerin oranı \%84,7 iken araştırmaya katılan işletme yöneticilerinin \%86,1'i diş kaynak kullanımının sabit maliyetleri değişken hale getirmediği görüşündedir. Ayrıca, hiç bir yönetici dış kaynak kullanımının maliyetleri yükselttiğini düşünmemektedir.

Tablo 5: Dıș kaynak Kullanımının Maliyetler Üzerine Etkisi

\begin{tabular}{|c|c|c|c|c|c|}
\hline $\begin{array}{l}\text { Dış kaynak Kullanımının Maliyetler Üzerine } \\
\text { Etkisi }\end{array}$ & İfadeler & $\mathbf{f}$ & $\%$ & $\bar{X}$ & S.s \\
\hline \multirow{2}{*}{ Sabit maliyetleri değişken hale getirir. } & Evet & 10 & 13,9 & \multirow{2}{*}{1,86} & \multirow{2}{*}{0,35} \\
\hline & Hayır & 62 & 86,1 & & \\
\hline \multirow{2}{*}{ Maliyetleri düşürür. } & Evet & 58 & 80,6 & \multirow{2}{*}{1,19} & \multirow{2}{*}{0,40} \\
\hline & Hayır & 14 & 19,4 & & \\
\hline \multirow{2}{*}{ Maliyetleri yükseltir. } & Evet & - & - & \multirow{2}{*}{2,0} & \multirow{2}{*}{0} \\
\hline & Hayır & 72 & 100,0 & & \\
\hline
\end{tabular}

Tablo 6'ya göre araştırmaya katılan işletme yöneticileri dış kaynak (tedarikçi) seçerken, öncelikli olarak diş kaynağın deneyim - tecrübesi $(\% 65,3)$ ile referans - kalite taahhütlerine $(\% 58,3)$ dikkat ettiği görülmektedir. Bunun yanında dış kaynağın teknik uzmanlığı $(\% 43,1)$ ile sorumluluk ve esnekliği $(\% 34,7)$ diğer kriterler olarak değerlendirildiği görülmektedir 
Tablo 6: Dış Kaynak Kullanımında Tedarikçi Seçiminde Dikkat Edilen Kriterler

\begin{tabular}{|c|c|c|c|c|c|}
\hline Kriterler & İfadeler & f & $\%$ & $\overline{\mathrm{X}}$ & S.S \\
\hline \multirow{2}{*}{ Teknik Uzmanlık } & Önemlidir & 31 & 43,1 & \multirow{2}{*}{1,57} & \multirow{2}{*}{0,50} \\
\hline & Önemli Değildir & 41 & 56,9 & & \\
\hline \multirow{2}{*}{ Deneyim-Tecrübe } & Önemlidir & 47 & 65,3 & \multirow{2}{*}{1,35} & \multirow{2}{*}{0,48} \\
\hline & Önemli Değildir & 25 & 34,7 & & \\
\hline \multirow{2}{*}{ Sağlam Referanslar-Kalite Taahhütleri } & Önemlidir & 42 & 58,3 & \multirow{2}{*}{1,42} & \multirow{2}{*}{0,50} \\
\hline & Önemli Değildir & 30 & 41,7 & & \\
\hline \multirow{2}{*}{ Finansal Sağlamlık } & Önemlidir & 18 & 25,0 & \multirow{2}{*}{1,75} & \multirow{2}{*}{0,44} \\
\hline & Önemli Değildir & 54 & 75,0 & & \\
\hline \multirow{2}{*}{ Sağlam Altyapı } & Önemlidir & 18 & 25,0 & \multirow{2}{*}{1,75} & \multirow{2}{*}{0,44} \\
\hline & Önemli Değildir & 54 & 75,0 & & \\
\hline \multirow{2}{*}{ Sorumluluk-Esneklik } & Önemlidir & 25 & 34,7 & \multirow{2}{*}{1,65} & \multirow{2}{*}{0,48} \\
\hline & Önemli Değildir & 47 & 65,3 & & \\
\hline \multirow{2}{*}{ İyi tanımlanmış Süreçler } & Önemlidir & 6 & 8,3 & \multirow{2}{*}{1,92} & \multirow{2}{*}{0,28} \\
\hline & Önemli Değildir & 66 & 91,7 & & \\
\hline \multirow{2}{*}{ Modern Olanaklar } & Önemlidir & 5 & 6,9 & \multirow{2}{*}{1,93} & \multirow{2}{*}{0,26} \\
\hline & Önemli Değildir & 67 & 93,1 & & \\
\hline
\end{tabular}

Tablo 7'de yöneticilerin dış kaynak kullanımına ilişkin görüşlerine yönelik ifadelerin faktör analizi sonuçları gösterilmiştir. Analiz sonucunda 0,50'nin altında faktör yükü alan değişkenler çıkartılmış ve altı faktör oluşmuştur. Oluşan faktörler sırasıyla, "maliyet", "iş gücü", "rekabet avantajı", "müşteri memnuniyeti", "sermaye yapısı" ve "hizmet kalitesi" şeklinde isimlendirilmiştir.

Tablo 7: Yöneticilerin Dıs Kaynak Kullanımına İliskin Görüslerine Yönelik İfadelerin Rotasyonlu Faktör Matrisi

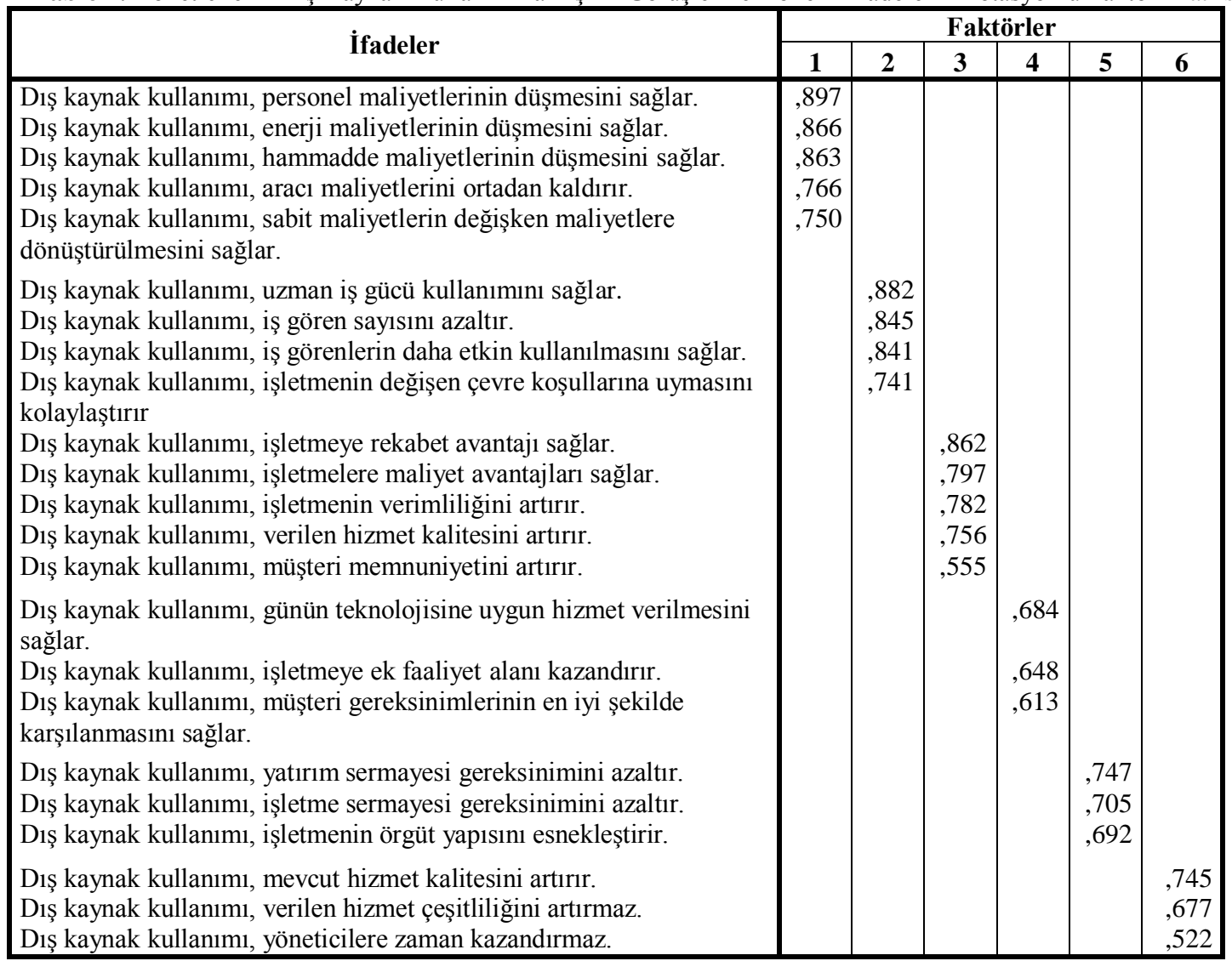

Faktör çıkarma metodu: Temel bileşenler analizi; Döndürme metodu: Verimax

Güvenirlik katsaylsı (Cronbach Alfa):0,72; KMO Örneklem Yeterliliği: \%70;

Bartlett's Küresellik Testi için Ki-Kare: 1150,668; $p=0,000<0.001$; Açlklanan toplam varyans: \%71,274. 
Tablo 8: Yöneticilerin Yöneticilik Tecrübesine Bağlı Olarak Yöneticilerin DKK'na İlişkin Görüşlerine Yönelik Oluşan Faktörlerin ANOVA Analizi Sonuçları

\begin{tabular}{|c|c|c|c|c|c|c|c|c|c|c|c|}
\hline & & $\mathbf{X}$ & S.S. & $\mathbf{F}$ & Sig. & & & $\mathbf{X}$ & S.S. & $\mathbf{F}$ & Sig. \\
\hline \multirow{7}{*}{ Faktör 1} & 0-1 Yil & 3,60 & 0,28 & \multirow{7}{*}{2,625} & \multirow{7}{*}{,032 } & \multirow{7}{*}{$\begin{array}{c}\text { Faktör } 4 \\
\text { Müşteri } \\
\text { Memnuniyeti }\end{array}$} & 0-1 Yil & 4,00 & 0,47 & \multirow{7}{*}{,833 } & \multirow{7}{*}{,531 } \\
\hline & 2-4 Y11 & 3,37 & 0,53 & & & & 2-4 Y 11 & 3,48 & 0,57 & & \\
\hline & 5-7 Y11 & 3,16 & 0,53 & & & & 5-7 Y 11 & 3,62 & 0,60 & & \\
\hline & 8-10 Y1l & 3,45 & 0,40 & & & & 8-10 Y1l & 3,88 & 0,53 & & \\
\hline & 11-14 Y1l & 4,00 & 0,51 & & & & 11-14 Y1l & 3,47 & 0,69 & & \\
\hline & $15 Y_{11} \geq$ & 3,34 & 0,51 & & & & $15 Y_{11} \geq$ & 3,72 & 0,43 & & \\
\hline & Toplam & 3,34 & 0,54 & & & & Toplam & 3,64 & 0,56 & & \\
\hline \multirow{7}{*}{ Faktör 2} & 0-1 Yil & 3,63 & 0,53 & \multirow{7}{*}{, 512} & \multirow{7}{*}{,767 } & \multirow{7}{*}{ Faktör 5} & 0-1 Yil & 4,00 & 0,00 & \multirow{7}{*}{,679 } & \multirow{7}{*}{,641 } \\
\hline & 2-4 Yil & 3,84 & 0,59 & & & & 2-4 Yil & 3,90 & 0,46 & & \\
\hline & 5-7 Y11 & 3,93 & 0,62 & & & & 5-7 Y1l & 3,69 & 0,49 & & \\
\hline & $8-10$ Yil & 4,19 & 0,59 & & & & $8-10 Y_{11}$ & 3,88 & 0,25 & & \\
\hline & 11-14 Y1l & 3,95 & 0,86 & & & & 11-14 Y1l & 3,87 & 0,61 & & \\
\hline & $15 Y_{11} \geq$ & 3,81 & 0,61 & & & & $15 Y_{11} \geq$ & 3,69 & 0,52 & & \\
\hline & Toplam & 3,91 & 0,61 & & & & Toplam & 3,77 & 0,47 & & \\
\hline \multirow{7}{*}{$\begin{array}{l}\text { Rekabet } \\
\text { Avantajı }\end{array}$} & 0-1 Y1l & 4,50 & 0,71 & \multirow{7}{*}{,923 } & \multirow{7}{*}{,472 } & \multirow{7}{*}{$\begin{array}{l}\text { Faktör } 6 \\
\text { Hizmet } \\
\text { Kalitesi }\end{array}$} & 0-1 Y1l & 3,50 & 0,24 & \multirow{7}{*}{2,980} & \multirow{7}{*}{,017 } \\
\hline & 2-4 Y11 & 4,23 & 0,42 & & & & 2-4 Y 11 & 3,29 & 0,47 & & \\
\hline & 5-7 Y11 & 4,27 & 0,46 & & & & 5-7 Y 11 & 3,41 & 0,54 & & \\
\hline & 8-10 Y1l & 4,38 & 0,31 & & & & 8-10 Y1l & 3,92 & 0,39 & & \\
\hline & 11-14 Y1l & 4,08 & 0,23 & & & & 11-14 Y11 & 2,93 & 0,28 & & \\
\hline & $15 Y_{11} \geq$ & 4,48 & 0,47 & & & & $15 Y_{11} \geq$ & 3,67 & 0,67 & & \\
\hline & Toplam & 4,30 & 0,44 & & & & Toplam & 3,46 & 0,56 & & \\
\hline
\end{tabular}

Tablo 8'de yöneticilerin yöneticilik tecrübesine bağlı olarak, yöneticilerin dış kaynak kullanımı görüşlerine yönelik oluşan faktörlerin ANOVA analizi sonuçları gösterilmektedir. Tabloya göre yöneticilerin yöneticilik tecrübeleri ile dış kaynak kullanımına ilişkin görüşleri arasında 0,05 anlamlll1k düzeyinde "maliyet" (F:2,625 p:0,032) faktörü ile "hizmet kalitesi" (F:2,980 p:0,017) faktöründe istatistikî olarak anlamlı farklılık gözlenmiştir. Buna istinaden yapılan Tukey HSD testinde 0,05 anlamlılık düzeyinde "maliyet" faktöründe 11-14 y1l tecrübesi olan yöneticiler ile 5-7 y1l tecrübesi olan yöneticiler arasında (p:0,013) farklılık oluştuğu tespit edilmiştir. "Hizmet kalitesi” faktöründe ise 11-14 yll tecrübesi olan yöneticiler ile
8-10 y1l tecrübesi olan yöneticiler arasında (p:0,020) farklılık oluştuğu gözlenmiştir. "İş gücü", "rekabet avantaj1", "müşteri memnuniyeti" ve "sermaye yapısı" faktörlerinde ise farklılık gözlenmemiştir. Buna göre oluşturulmuş olan $\mathrm{H}_{2}$ hipotezi reddedilmiștir. Bunun yanında yöneticilerin eğitim durumlarına bağlı olarak, yöneticilerin dış kaynak kullanımı görüşlerine yönelik oluşan faktörler ile dış kaynak kullanım alanlarının ANOVA analizi sonuçları ve yöneticilerin yöneticilik tecrübesine bağlı olarak, dış kaynak kullanım alanlarının ANOVA analizi sonuçlarında farklılık saptanmamıştr. Buna bağlı olarak oluşturulmuş olan $\mathrm{H}_{1}, \mathrm{H}_{3}$ ve $\mathrm{H}_{4}$ hipotezleri ise kabul edilmiştir.

Tablo 9: Ulaştırma-Taşımacılık-Lojistik Alanı ile Finansal Performansa İlişkin İfadelerin "T" Testi Sonuçları

\begin{tabular}{|c|c|c|c|c|c|c|c|c|c|c|}
\hline & & \multirow{2}{*}{\multicolumn{2}{|c|}{$\begin{array}{l}\text { Varyansların } \\
\text { Eşitliği İçin } \\
\text { Levene Testi }\end{array}$}} & \multirow{2}{*}{\multicolumn{3}{|c|}{$\begin{array}{l}\text { Ortalamaların Eşitliği } \\
\text { İçin t-Testi }\end{array}$}} & \multicolumn{4}{|c|}{ Grup İstatistikleri } \\
\hline & & & & & & & \multicolumn{2}{|c|}{ Yararlanıyoruz } & \multicolumn{2}{|c|}{ Yararlanmiyoruz } \\
\hline & & $\mathbf{F}$ & Sig. & $\mathbf{t}$ & df & $\begin{array}{l}\text { Sig. (2- } \\
\text { tailed) }\end{array}$ & $\mathbf{X}$ & S.S & $\mathbf{X}$ & S.S \\
\hline \multirow{2}{*}{$\begin{array}{l}\text { Gelirlerimizin } \\
\operatorname{artışı~}\end{array}$} & $\begin{array}{l}\text { Varyanslar } \\
\text { Eşit }\end{array}$ & ,752 & ,389 & 1,287 & 70 & ,202 & \multirow{2}{*}{3,5789} & \multirow{2}{*}{,68306 } & \multirow{2}{*}{3,3824} & \multirow{2}{*}{,60376 } \\
\hline & $\begin{array}{l}\text { Varyanslar } \\
\text { Eşit Değil }\end{array}$ & & & 1,296 & 69,992 & ,199 & & & & \\
\hline \multirow{2}{*}{$\begin{array}{c}\text { Pazar payı } \\
\text { büyüklüğümüz }\end{array}$} & $\begin{array}{l}\text { Varyanslar } \\
\text { Eşit }\end{array}$ & 25,009 & ,000 & 2,150 & 70 & ,035 & \multirow{2}{*}{3,5000} & \multirow{2}{*}{,79695 } & \multirow{2}{*}{3,1765} & \multirow{2}{*}{,38695 } \\
\hline & $\begin{array}{l}\text { Varyanslar } \\
\text { Eşit Değil }\end{array}$ & & & 2,226 & 54,801 & ,030 & & & & \\
\hline \multirow{2}{*}{$\begin{array}{c}\text { Ciro karlılı̆̆ımız } \\
\text { (Kar/Toplam } \\
\text { Satışlar) }\end{array}$} & $\begin{array}{l}\text { Varyanslar } \\
\text { Eşit }\end{array}$ & 14,240 & ,000 & 1,124 & 70 & ,265 & \multirow{2}{*}{3,2895} & \multirow{2}{*}{,80229 } & \multirow{2}{*}{3,1176} & \multirow{2}{*}{,40934 } \\
\hline & $\begin{array}{l}\text { Varyanslar } \\
\text { Eşit Değil }\end{array}$ & & & 1,162 & 56,317 &, 250 & & & & \\
\hline \multirow{2}{*}{$\begin{array}{l}\text { Toplam aktif } \\
\text { (varlık) } \\
\text { karlılığımız }\end{array}$} & $\begin{array}{l}\text { Varyanslar } \\
\text { Eşit }\end{array}$ & 10,640 &, 002 & 1,632 & 70 &, 107 & \multirow{2}{*}{3,4211} & \multirow{2}{*}{, 75808} & \multirow{2}{*}{3,1765} & \multirow{2}{*}{,45863 } \\
\hline & $\begin{array}{l}\text { Varyanslar } \\
\text { Eşit Değil }\end{array}$ & & & 1,675 & 61,857 & ,099 & & & & \\
\hline \multirow{2}{*}{$\begin{array}{l}\text { Öz sermaye } \\
\text { karlılığımız } \\
\text { (Kar/ Öz } \\
\text { Sermaye) }\end{array}$} & $\begin{array}{l}\text { Varyanslar } \\
\text { Eşit }\end{array}$ & 2,084 & , 153 & 1,690 & 70 & ,096 & \multirow{2}{*}{3,5789} & \multirow{2}{*}{,68306 } & \multirow{2}{*}{3,3235} & \multirow{2}{*}{,58881 } \\
\hline & $\begin{array}{l}\text { Varyanslar } \\
\text { Eşit Değil }\end{array}$ & & & 1,704 & 69,912 & ,093 & & & & \\
\hline
\end{tabular}


K. Çatı, İ. Çömlekçi, E. Zengin / KMÜ Sosyal ve Ekonomik Araştırmalar Dergisi 17 (28): 56-67 2015

Tablo 9'de ulaştırma-taşımacılık ve lojistik alanı ile finansal performansa ilişkin ifadelerin T-testi sonuçları gösterilmektedir. Tabloya göre 0,05 anlamlılık düzeyinde pazar payı büyüklüğünde istatistikî (t:2,226 p:0,030) olarak anlamlı bir farkın olduğu belirlenmiştir. Buna göre araştırma kapsamındaki işletmelerin ulaştırma-taşımacılık ve lojistik alanında dış kaynaktan yararlanması işletmenin pazar payını büyüttüğü söylenebilir. Bu bağlamda oluşturulan $\mathrm{H}_{5 \mathrm{f}}$ hipotezi reddedilmiştir. Bunun yanında araştırma kapsamındaki KOBİ’lerin yararlandığı diğer dış kaynak kullanım alanları olan; bilgi-işlem teknolojileri, güvenlik hizmetleri, eğitim faaliyetleri, tanitım ve reklam faaliyetleri, muhasebe ve finans alanı, temizlik hizmetleri, teknik bakım hizmeti, yemek hizmetleri alanları ile finansal performansa ilişkin ifadeler için yapıllan t-testlerinde 0,05 anlamlılık düzeyinde farklılık gözlemlenmemiștir. Dolayısı ile $\mathrm{H}_{5 \mathrm{a}}, \mathrm{H}_{5 \mathrm{~b}}, \mathrm{H}_{5 \mathrm{c}}, \mathrm{H}_{5 \mathrm{~d}}$, $\mathrm{H}_{5 \mathrm{e}}, \mathrm{H}_{5 \mathrm{~g}}, \mathrm{H}_{5 \mathrm{~h}}$ ve $\mathrm{H}_{5 \mathrm{i}}$ hipotezleri ise kabul edilmiştir. $\mathrm{Bu}$ bağlamda, işletmelerin bu alanlardan yararlanma veya yararlanmama durumlarının işletmelerin finansal performansı üzerine etkisinin olmadığı saptanmıştır. Analizlerde, dış kaynak kullanım alanlarından, "satış-pazarlama", "satın alma", "insan kaynakları-personel seçimi" ve "çağrı merkezi" alanları araştırma kapsamındaki işletmeler tarafindan kullanılmamasından dolayı kapsam dışı bırakılmıştır.

Tablo 10: Yöneticilerin DKK'na İlişkin Görüşlerine Yönelik Oluşan Faktörlere Bağlı Olarak Finansal Performans İfadelerinin ANOVA Analizi Sonuçları

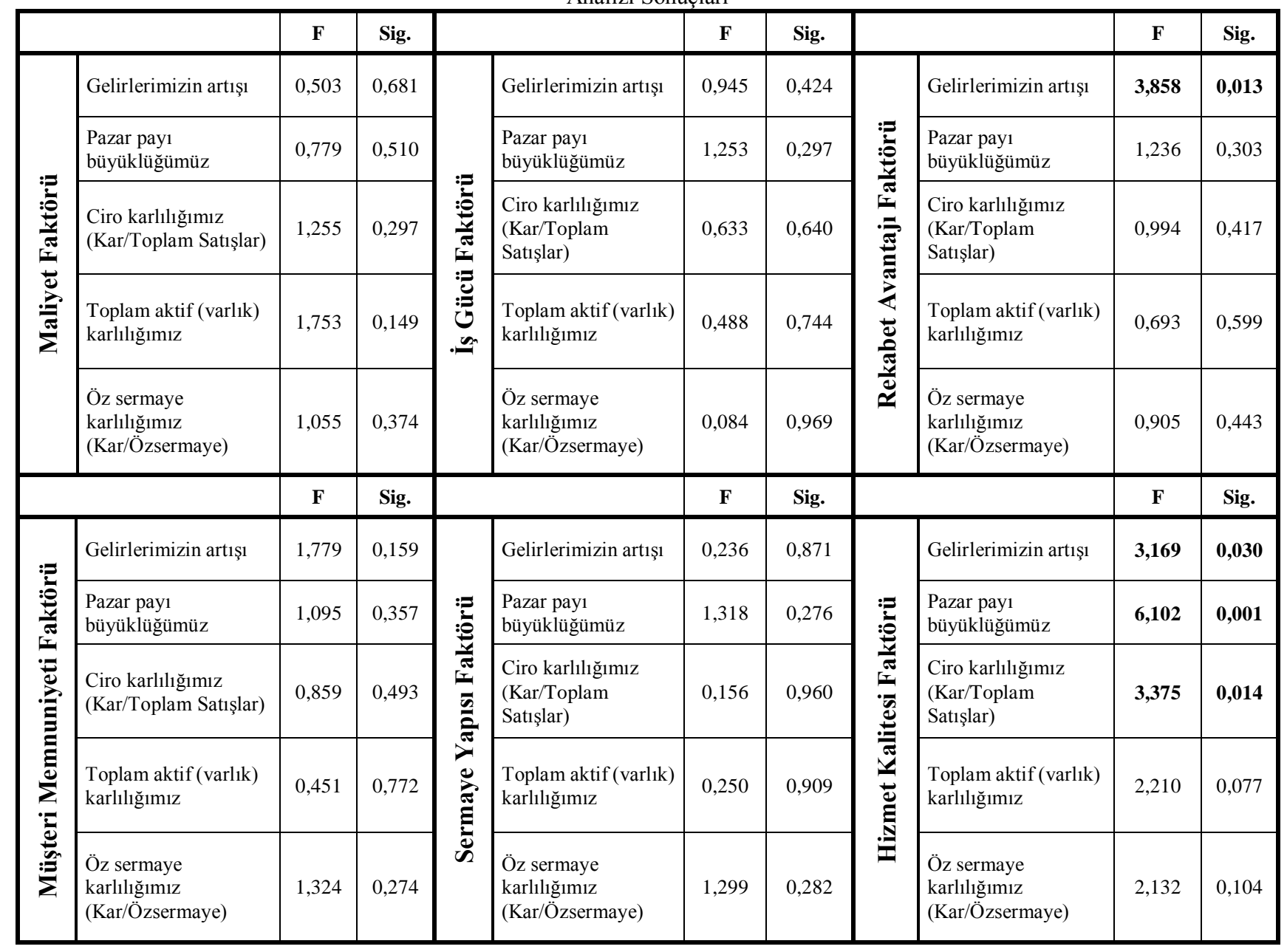

Tablo 10'da yöneticilerin DKK'na ilişkin görüşlerine yönelik oluşan faktörlere bağlı olarak finansal performans ifadelerinin Anova analizi sonuçları gösterilmektedir. Tabloya göre yöneticilerin DKK'na ilişkin görüşlerine yönelik oluşan faktörlerden "rekabet avantajı" faktörü ile finansal performans ifadelerinden "gelirlerimizin artışı" arasında 0,05 anlamlılık düzeyinde (F:3,858 p:0,013) istatistikî olarak anlamlı farklılık gözlenmiştir. "Hizmet kalitesi" faktörü ile finansal performans ifadelerinden "gelirlerimizin artışı" (F:3,169 p:0,030) arasında, "pazar payı büyüklüğü" (F:6,102 p:0,001) arasında ve "Ciro karlılığı" (F:3,375 p:0,014) arasında 0,05 anlamlllık düzeyinde istatistikî olarak anlamlı farklılık tespit edilmiștir. Buna göre oluşturulmuş olan $\mathrm{H}_{6}$ hipotezi kabul edilmiştir.

\section{Sonuc}

Küreselleşmenin etkisiyle rekabette yaşanan çetin çekişmeler, işletmeleri bir dizi stratejik hamleye zorlamaktadır. Bu çekişmeler içerisinde yönetim stratejisi olarak yapılan hamlelerin başında dıș kaynak kullanımı gelmektedir. İşletmeler diş kaynak kullanarak temel yeteneklerine odaklanmayı hedeflemekte ve rekabet yarışında öne geçebilecek yenilikler ve avantajlar oluşturabilmektedirler. Bu açıdan bakıldığında KOBİ'lerin dıș kaynak kullanımı konusundaki durumlarının hassasiyetle incelenmesi bulundukları ekonomiye katkı açısından önemlidir.

Araştırma kapsamındaki KOBİ'lerin \%90,3'ü dıș kaynak kullanımını stratejik bir karar olarak nitelendirmektedir. KOBİ'lerin dış kaynak kullanmadaki öncelikli amacı; dış kaynağa konu olan faaliyette kendilerini yetersiz 
K. Çatı, İ. Çömlekçi, E. Zengin / KMÜ Sosyal ve Ekonomik Araştırmalar Dergisi 17 (28): 56-67 2015

görmeleridir. Bunun yanında faaliyet esnekliği sağlamak ve ana faaliyetlere odaklanarak kaynakları verimli kullanmak önde gelen diğer amaçlardır. KOBİ'ler dış kaynak tercihi sırasında dış kaynağın, deneyimi, tecrübesi, referansları, kalite taahhütleri ve teknik uzmanlığına dikkat ederek seçim yaptıkları gözlenmiştir. Buna göre KOBİ'lerin \%80,6's1 dış kaynak kullanımının maliyetleri düşürdüğünü dile getirmişlerdir. Yani dış kaynak yoluyla teknik konuda gelişmiş, kalite konusunda kendini kanıtlamış, hizmeti satın alarak uzun vadede maliyet avantajı sağladıkları söylenebilir.

Araştırma kapsamındaki KOBİ yöneticilerinin dış kaynak kullanımına bakış açıları faktör analizi sonucunda altı faktörde toplanmıştır. Yöneticilerin dış kaynak kullanımına bakış açılarına yönelik oluşan faktörler yöneticilerin eğitim durumlarına bağlı olarak karşılaştırılmış ve her hangi bir farklılık saptanmamıştır. Yine yöneticilerin dış kaynak kullanımına bakış açılarına yönelik oluşan faktörler yöneticilerin yöneticilik tecrübelerine bağlı olarak karşılaştırılmıştır. Sonucunda maliyet faktörü ve hizmet kalitesi faktöründe anlamlı farklılık saptanmıştır. Maliyet faktöründeki farklılığın 11-14 y1l tecrübesi olan yöneticiler ile 5-7 yıl tecrübesi olan yöneticiler arasında oluştuğu tespit edilmiştir. "Hizmet kalitesi" faktöründe ki farklılık ise 11-14 yıl tecrübesi olan yöneticiler ile 8-10 y1l tecrübesi olan yöneticiler arasında oluştuğu belirlenmiştir. Yöneticilerin yöneticilik tecrübesi ve eğitim durumlarına bağlı olarak dış kaynak kullanım alanları incelenmiş ve sonucunda farklılıklar saptanmamıştır. Buna göre, dış kaynaklardan yararlanma veya yararlanmama durumlarına yöneticilerin eğitim durumunun ve yöneticilik tecrübesinin etkisinin olmadığı belirlenmiştir.

Araştırmanın temel amacı kapsamında dış kaynak kullanım alanlarına bağlı olarak işletmenin finansal performansı incelenmiştir. Araştırma kapsamındaki KOBİ'lerin dış kaynaklardan yararlandıkları alanlardan ulaştırma-taşımacılık ve lojistik alanında finansal performansa ilişkin ifadelerden pazar payı büyüklüğünde farklılık gözlenmiştir. Araştırma kapsamındaki KOBİ'lerin ulaştırma-taşımacılık ve lojistik alanında diş kaynak kullanmalarının pazar paylarının büyümesi konusunda etkisi olmaktadır. Diğer finansal performans ifadelerinde ise farklılık gözlenmemiştir. Bunun yanında araştırma kapsamındaki yararlanılan diğer dış kaynak kullanım alanlarında finansal performansa ilişkin ifadelerde farklılık tespit edilmemiştir. $\mathrm{Bu}$ bağlamda, KOBİ'lerin dış kaynaklardan yararlanma veya yararlanmama durumlarının ulaştırma-taşımacılık ve lojistik alanı dışında işletme finansal performansı üzerinde herhangi bir etkisi olmadığı saptanmıştır. Buna göre işletmelerin dış kaynak kullanımını stratejik bir karar olarak nitelendirdikleri göz önüne alındığında, yararlanılan dış kaynak alanlarının finansal performanslarına etki edecek alanlar olmadığı ve KOBİ'lerin dış kaynak kullanma konusunda çekingen davrandıkları söylenebilir.

Son olarak yöneticilerin dış kaynak kullanımı ile ilgili görüşlerinin finansal performans üzerindeki etkisine yönelik yapılan analizler sonucunda "rekabet avantajı" faktöründe gelirlerin artışı konusunda anlamlı farklılık gözlenmiştir. "Hizmet kalitesi" faktöründe ise gelirlerin artışı, pazar payı büyüklüğü ve ciro karlılığında anlamlı farklılık saptanmıştır. $\mathrm{Bu}$ bağlamda yöneticiler dış kaynak kullanarak rekabet avantajı sayesinde gelirlerini artırabilmekte ve hizmet kalitesine bağlı olarak pazarda daha çok pay sahip olmakta, bu sayede gelirlerini arttırarak ciro karlılığını yükseltebilmektedirler. Ayrıca maliyet tasarrufu sağlamanın dış kaynak kullanım amaçlarında öncelikli olmamasına rağmen dış kaynak kullanımının maliyetler üzerinde olumlu bir etkiye sahip olduğu sonucuna ulaşılmıştır.

Uluslararası işletmelere bakıldığında ise (NIKKE, Coca Cola gibi), dış kaynak kullanımı yoluyla organizasyon yapılarını küçülterek, markayı etkin kullanma ve ana faaliyet konularına odaklanma yoluyla bunu performanslarına yansitabilmektedirler. $\mathrm{Bu}$ bağlamda, KOBİ'lerin çekingen yapıdan çıkarak ve profesyonel yönetim bakış açısıyla değerlendirerek dış kaynakları daha etkin kullanmaları gerekmektedir. $\mathrm{Bu}$ anlamda yapılan çalışmaların artması olası sorunlara çözümler oluşturulması ve bilgi eksikliğinin giderilmesi KOBI'lerin ve dolayısıyla ülke ekonomisinin gelişmesine katkı sağlayacaktır.

\section{Kaynaklar}

Arvanitis, S. And Loukis E. N. (2011), "Outsourcing and Firm Performance - A Comparative Study of Swiss and Greek Firms", KOF Working Papers.

Ataman, G. (2001), İşletme Yönetimi Temel Kavramlar \& Yeni Yaklaşımlar. Türkmen Kitapevi, İstanbul.

Büber, İ. (1999), İnsan Kaynakları Yönetiminde Dış Kaynaktan Yararlanma ve Seçilmiş Sektörler İtibarıyla İşçiİşveren Sendikalarının Görüşlerine Yönelik Bir Araştırma, İstanbul Üniversitesi, Sosyal Bilimler Enstitüsü, Yüksek Lisans Tezi, İstanbul.

Calabrese, G. And Erbetta, F. (2004), "Outsourcing And Firm Performance: Evidence From Italian Automotive Suppliers", 13th Annual IPSERA Conference, Università di Catania, 4-7 April Catania.

Erkaragülle, S. (2007), Yönetici Gözüyle İşletmelerde Dış Kaynaklardan Yararlanmanın Başarısını Etkileyen Faktörlerin Bir İşletme Üzerinde İncelenmesi, Osmangazi Üniversitesi, Sosyal Bilimler Enstitüsü, Yüksek Lisans Tezi, Eskişehir.

Genç, N. (2004), Yönetim ve Organizasyon, Seçkin Yayınevi, Birinci Baskı, Ankara.

Gorzig, B. and Stephan, A. (2002), Outsourcing And Firm-Level Performance, German Institute For Economic Research (DIW Berlin).

Heıkkıla, Jussi and Carlos Cordon (2002). Outsourcing: A Core or Non-core Strategic Management Decision?, Strategic Change, Vol.11, 183-193.

Jennıngs, David (1997), Strategic guidelines for outsourcing decisions, Strategic Change, Vol.6, 85-96.

Karakaş, Y. E. (2012), Otel İşletmelerinde Dış Kaynak Kullanımı: Alanya'da Faaliyette Bulunan Dört Ve Beş Yıldızlı Otellerde Bir Araştırma, Akdeniz Üniversitesi, Sosyal Bilimler Enstitüsü, Turizm İşletmeciliği ve Otelcilik Ana Bilim Dalı, Yüksek Lisans Tezi, Antalya.

Karacaoğlu, K., (2001), Dış Kaynaklardan Yararlanma ve Teknoloji İle İlgili Dış Kaynaklardan Yararlanmanın Türkiye'de Bankacılık Sektöründe Uygulamaları, Niğde Üniversitesi, Sosyal Bilimler Enstitüsü, Yüksek Lisans Tezi, Niğde.

Kabakçı, Y. (2008), Sermaye Yapısı İle İşletme Performansı Arasındaki İlişki: Gıda Sektöründe Bir Uygulama, Ege Akademik Bakış Dergisi, 167-182. 
Karahan, A. (2009), Dış Kaynak Kullanımının Verimlilik Üzerine Etkisi Hastane Yöneticileri Üzerine Bir Araştırma, Balıkesir Üniversitesi, Sosyal Bilimler Enstitüsü Dergisi, Cilt: 12, Sayı: 21, 185-199

Kalkan, A. (2005), KOBİ'lere Sağlanan Desteklerin Örgütsel Performansına Etkileri, Yayımlanmamış Doktora Tezi, Gebze Yüksek Teknoloji Enstitüsü, Kocaeli.

Küçük ve Orta Büyüklükteki İşletmelerin Tanımı, Nitelikleri ve Sınıflandırılması Hakkında Yönetmelikte Değişiklik Yapılmasına Dair Yönetmelik (2012). T.C. Resmi Gazete, 28457, 4 Kasim 2012.

Mucuk, İ. (2000), Modern İşletmecilik, Türkmen Kitapevi, 12. Basım, İstanbul.

Nunnally, J.C. ve Bernstein, I. H. (1994), Psychometric Theory (3. Basım). McGraw-Hill: New York.

Oktay, E. (2006). Stratejik Yönetim Sürecinde Performans Geliştirmenin Bir Aracı Olarak Dış Kaynak Kullanımı: İmalat Sanayisinde Bir Uygulama, Selçuk Üniversitesi Sosyal Bilimler Enstitüsü, Doktora Tezi, Konya.

Ordoobadi, S. (2005), Development of a Decision Model for Strategic Outsourcing, Journal of Applied Business and Economics.

Özdoğan, O. N. (2006), Otel İşletmelerinde Faaliyet Alanlarıaçısından Dış Kaynak Kullanımı (Outsourcıng) Ve Finansal Performans Üzerine Etkileri, Dokuz Eylül Üniversitesi, Sosyal Bilimler Enstitüsü, Turizm İşletmeciliği Anabilim Dalı, Doktora Tezi, İzmir.

Sanal1:

http://tr.wikipedia.org/wiki/D\%C4\%B1\%C5\%9F_kaynak_ku llan\%C4\%B1m\%C4\%B1, (Son Erişim: 20.03.2014)

Sanal2:

http://www.flatworldsolutions.com/articles/advantagesdisadvantages-outsourcing.php (Son Erişim: 26.03.2014)

Sanal3:

http://www.globaloutsourcingagency.com/adv.html

Erişim: 26.03.2014)

Şağban, A. (2011), Lojistik Hizmetlerde Diş Kaynaklardan Yararlanmanın İşletme Başarısına Etkisi: Çorum Organize Sanayi Bölgesi Örneği, Hitit Üniversitesi Sosyal Bilimler Enstitüsü İşletme Anabilim Dalı, Yüksek Lisans Tezi, Çorum.

Şahin, B. (2005), İşletmelerde Dış Kaynaklardan Yararlanma Ve Konaklama İşletmeleri Üzerinde Bir Uygulama, Balıkesir Üniversitesi, Sosyal Bilimler Enstitüsü, Turizm İşletmeciliği Ve Otelcilik Ana Bilim Dalı, Yüksek Lisans Tezi, Balıkesir.

Turgut, H. (2012), Otel İşletmelerinde Diş Kaynak Kullanımının Başarısına Ortaklık Kalitesinin Etkisi, Ulusal Meslek Yüksekokulları Çalıştayı ve Öğrenci Sempozyumu, Nevşehir Üniversitesi, 13-15 Haziran.

Y1lmaz, H. ve Karahan, A. (2010), Yüksek Performans kültürünün Geliştirilmesi ve Firma Başarısına Etkileri, Selçuk Üniversitesi Sosyal Bilimler Enstitüsü Dergisi, (23), 273-282. 